\title{
The relationship between the geochemical and mineralogical characteristics of Calcocambisol, colluvium and recent marine lake sediment of the narrow seashore intertidal zone: a case study from the Veliko Jezero (Mljet Island, Croatia)
}

\author{
Stanko Ružičić ${ }^{1, *}$, Goran Durn ${ }^{1}$, Ivan Sondi ${ }^{1}$, Lucija Mihaljević ${ }^{1}$ and Maja Ivanić2 \\ ${ }^{1}$ University of Zagreb, Faculty of Mining, Geology and Petroleum Engineering, Pierottijeva 6, HR-10000 Zagreb, Croatia; \\ (*corresponding author: stanko.ruzicic@rgn.unizg.hr) \\ 2 Ruđer Bošković Institute, Division for Marine and Environmental Research, Bijenička cesta 54, HR-10000 Zagreb, Croatia
}

doi: $10.4154 / g c .2021 .10$

\section{Article history:}

Manuscript received December 09, 2020 Revised manuscript accepted March 22, 2021 Available online June 30, 2021

\begin{abstract}
This study investigates the mineral composition, particle size distribution and geochemical characteristics of Calcocambisol, colluvium and recent marine lake sediment in a narrow intertidal seashore zone of the Veliko Jezero on the Island of Mljet (Croatia). The obtained results show that the fractions of Calcocambisol/colluvium less than $2 \mathrm{~mm}$ and $2 \mu \mathrm{m}$ display similar particle size distribution (PSD) curves compared to marine lake sediments containing larger particles in these fractions. The smallest fractions of the investigated materials that are less than $1 \mu \mathrm{m}$ show identical PSD curves. The bulk and clay mineral composition of the marine lake sediment show that the non-carbonate fraction is derived from weathering of the surrounding soils and colluvium containing quartz, feldspars and phyllosilicates (illitic material, kaolinites, chlorite, and a mixedlayer clay mineral, MLCM), as well as the authigenic formation of early-diagenetic pyrite, while one part is related to the yield of material by aeolian deposition (amphibole). The observed difference between the phyllosilicate mineral phases in the clay fraction of the Calcocambisol/colluvium and the carbonate-free clay fraction of the marine lake sediment is related to 1) the presence of chlorite in the marine lake sediment and 2) the higher content of MLCM in the Calcocambisol/colluvium. The chlorite in the marine lake sediment was inherited from the Calcocambisol/colluvium as a result of soil erosion prior to its complete destabilization in the soil. High Chemical Index of Alteration (CIA) values in the Calcocambisol and colluvium clearly indicate their intense weathering. Based on the $\mathrm{Sm} / \mathrm{Nd}$ and Ti/Al ratios, it can be concluded that the aluminosilicates in the Calcocambisol, colluvium and marine lake sediment are of the same provenance. The distribution of each analysed element among the sequential fractions is very similar in both the Calcocambisol and colluvium. The highest concentrations for most of trace elements in the Calcocambisol, colluvium and marine lake sediment was determined in their residual fraction. $\mathrm{Mn}, \mathrm{Co}$ and $\mathrm{Pb}$ show a different partitioning between the Calcocambisol/colluvium and marine lake sediment, respectively.
\end{abstract}

Keywords: Calcocambisol, colluvium, marine lake sediment, mineralogy, geochemical characterization
However, systematic studies of the influence of soils on the formation and geochemical characteristics of recent sediments from the seashore intertidal zone of the Adriatic Sea have, to our knowledge, rarely been reported in the literature (SONDI et al., 1994; JURINA et al., 2015).

ROGAN ŠMUC et al. (2018) studied the distribution of heavy metals in surface sediments from Koper Bay (north Adriatic Sea) using a sequential extraction procedure. The authors found that the majority of the analyzed metals could be considered immobile due to their high affinity for binding to the residual phase.

It is well-known that the presence and distribution of the mineral phase gives an indication of the origin of the material of which the sediments are composed. Numerous studies of mineral distributions in recent marine sediments dealing with this issue have been implemented (TOMADIN, 2000; GOVORČIN et al., 2001; SONDI \& JURAČIĆ, 2010). Most recently, IVANIĆ et al. (2020) analyzed the mineral composition of recent marine sediments and concluded that the dominant input of terrigenous material into the Mljet marine lake system is limited to soil erosion and aeolian deposition. Previous studies (SONDI \& JURAČIĆ, 2010) of the Mljet Lakes have shown that the authigenic formaand recent sedimentation processes. 

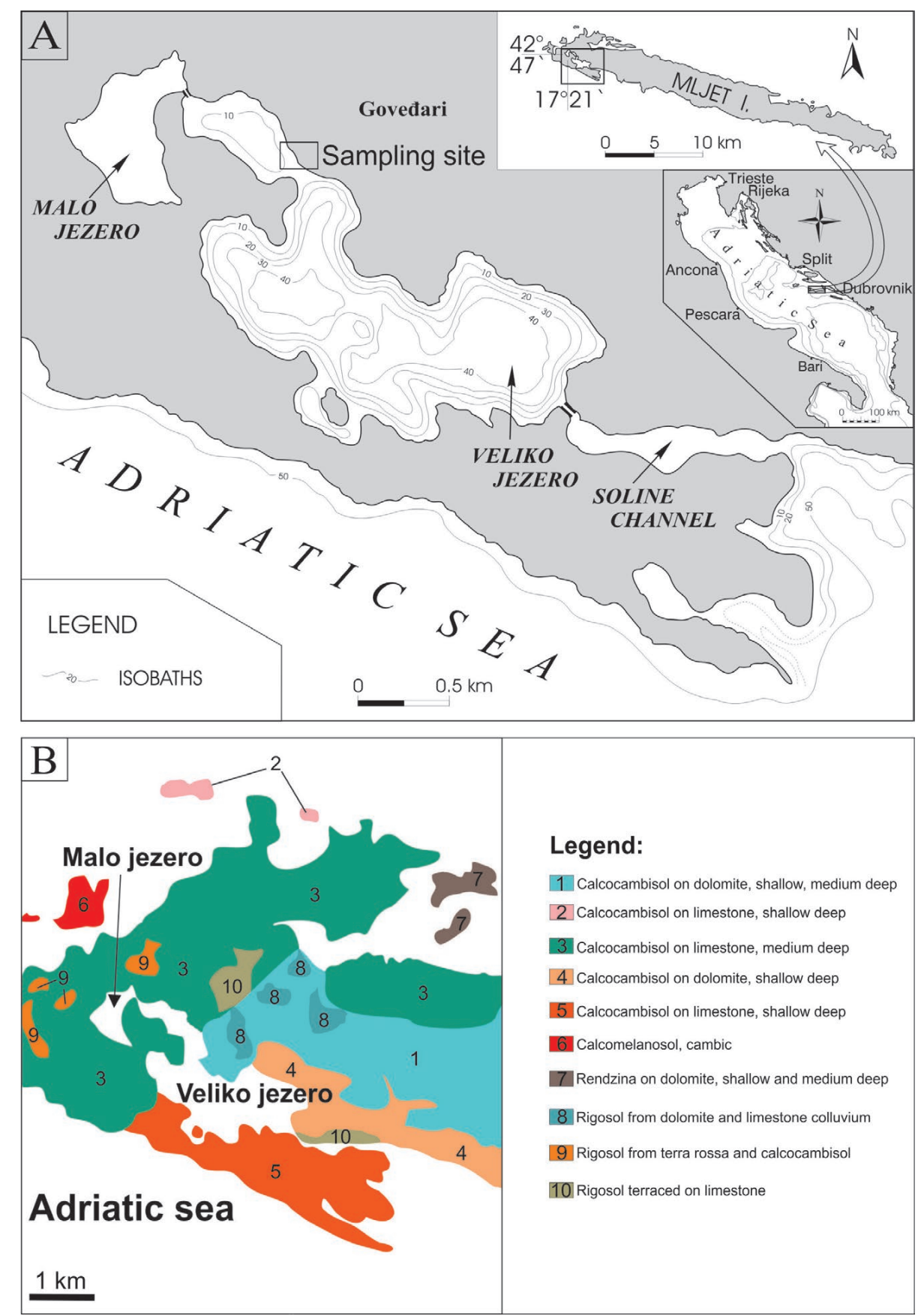

Figure 1. Geographical map of the western part of Mljet Island with the sampling locations (A) and with corresponding pedological map (B) (modified after MARTINOVIĆ, 1982).

tion of aragonite is the main source of sedimentary material in the deeper parts of the Mljet Lakes, while Mg-calcite is the product of biomineralization. Calcite and a small amount of dolomite are derived from the surrounding carbonate rocks. Until now, no studies have been conducted in the Mljet Lakes that would indicate the role of weathering of Calcocambisols and colluvium and their contribution to the formation of recent sediments and the distribution of trace elements in the intertidal seashore zone of the Mljet marine lakes.

This study aims to investigate the influence of local soil (Calcocambisol) and colluvium (consisting of soil and rock fragments accumulated on the lower parts of the slopes along the lakeshore) as a potential detrital source material for marine lake sediments of the intertidal zone of the Veliko Jezero. In addition, the influence of soil wear on the geochemical distribution of trace ele- ments in this zone was also investigated. Accordingly, this study is based on detailed mineralogical and geochemical analyses (sequential extraction analysis and selected geochemical indicators).

\section{STUDY AREA}

The Veliko Jezero (the part of the Mljet Lakes system) is located on the western part of the island of Mljet (Adriatic Sea) (Fig. 1A). The geological features of this area were described in detail by KOROLIJA et al. (1977) and GUŠIĆ et al. (1995). According to KOROLIJA et al. (1977), Mljet Island is divided into two geological units: Mesozoic carbonate deposits, which form most of the island, and Quaternary deposits, which are sporadically present on the Mesozoic carbonates. The Mesozoic carbonates are divided into the Upper Jurassic limestones, Jurassic-Cretaceous dolomites, Lower Cretaceous limestones, and Cretaceous lime- 
stones and dolomites. The lower Cretaceous limestone is characterized by laminated and fenestrae mudstone.

This setting is characterized by several karst depressions (sinkholes or dolines) formed under subaerial exposure. Some of these depressions are submerged today due to Holocene sea-level rise (SURIĆ et al., 2005), one of which is the present-day Veliko Jezero. Since the semi-enclosed water bodies of Veliko Jezero are loosely connected to the open sea, they contain seawater and can therefore be called marine lakes (BAKRAN-PETRICIOLI \& PETRICIOLI, 2008; SONDI \& JURAČIĆ, 2010).

The main soil types on Mljet Island are Calcocambisol, Rendzina, and Calcomelanosol (MARTINOVIĆ, 1982) (Fig. 1B). According to MARTINOVIĆ (1982), the most common soil type in the study area is Calcocambisol. This soil was developed on Lower Cretaceous limestone and Jurassic dolomite (GUŠIĆ et al., 1995).

\section{MATERIALS AND METHODS}

\subsection{Fieldwork and sampling}

The Calcocambisol, colluvium, and recent marine lake sediment were collected during field investigations in June 2015. The first sample was a subsurface soil taken from a depth of up to $20 \mathrm{~cm}$ and represents the $\mathrm{B}$ horizon (VJ-1A). It was determined as a Calcocambisol (Fig. 2A, and B). Sample (VJ-1B) (Fig. 2A and C), was sampled in a flat area of the Veliko Jezero coastal zone and determined as colluvium. Colluvium is situated in contact with the Veliko Jezero and besides the erosion and accumulation of materials and formation of the colluvial soil, there is occasional flooding during tides from the lake. The third sample (VJ-1C) was collected from surface marine lake sediment (at a depth of approx. $2 \mathrm{~m}$ ) originating from the Veliko Jezero (Fig. 2A).

\subsection{Laboratory methods}

A portion of each sample was crushed and sieved through a $2 \mathrm{~mm}$ sieve for physical, chemical, and mineralogical analyses. The $<2 \mu \mathrm{m}$ and $<1 \mu \mathrm{m}$ fractions of the soil samples were separated by sedimentation in a cylinder and quantitatively obtained after the appropriate settling time. The $\mathrm{pH}$, both in $\mathrm{H}_{2} \mathrm{O}$ and $\mathrm{KCl}(\mathrm{c}=1 \mathrm{M})$, was measured in the 1:5 suspension (ISO 10390, 2005). Electrical conductivity of the samples was measured in water with a soil to water ratio of 1:5 using a Cond 3110 WTW EC meter (ISO 11265, 1994).

Particle-size distribution (PSD) measurements were performed using laser diffraction (LS 13320, Beckman Coulter Inc., USA). Prior to measurements, the samples were dispersed in deionized water, left to soak overnight, and sonicated for $5 \mathrm{~min}$ before analysis. The particle size was calculated with proprietary software using the Mie theory of light scattering (optical parameters: refractive index, 1.53; absorption index, 0.1).

The mineral composition of the $<2 \mathrm{~mm},<2 \mu \mathrm{m}$, and $<1 \mu \mathrm{m}$ fractions of the analyzed samples was determined by X-ray powder diffraction (XRD) using a Philips diffractometer (graphite monochromator, $\mathrm{CuK} \alpha$ radiation, proportional counter). Identification of clay minerals was based on the methods outlined by BROWN (1961), BRINDLEY \& BROWN (1980), and MOORE \& REYNOLDS (1989). Semi-quantitative mineral composition of all fractions was determined by comparison with standards of mixed minerals (quartz, plagioclase, halite, and carbonates). The carbonate content was determined by the volumetric method (ISO 10693, 1995). Iron and manganese extractable with $\mathrm{Na}$ dithionite-citrate bicarbonate $\left(\mathrm{Fe}_{\mathrm{d}}, \mathrm{Mn}_{\mathrm{d}}\right)$ were obtained using the method of MEHRA \& JACKSON (1960), while proportions extractable with ammonium oxalate $\left(\mathrm{Fe}_{0}, \mathrm{Mn}_{0}\right)$ were acquired according to SCHWERTMANN (1964). The organic matter (OM) from the samples was removed using sodium hypochlorite (Na$\mathrm{OCl}$ ) according to the slightly modified treatment proposed by KAISER \& GUGGENBERGER (2003). The total organic carbon (TOC) content of the samples (after dilution of organic matter and carbonates) was determined by combustion of acid-insoluble matter in a Leco IR-212 carbon analyser (USA), after treatment with hot $1: 1$ diluted $18 \% \mathrm{HCl}$.
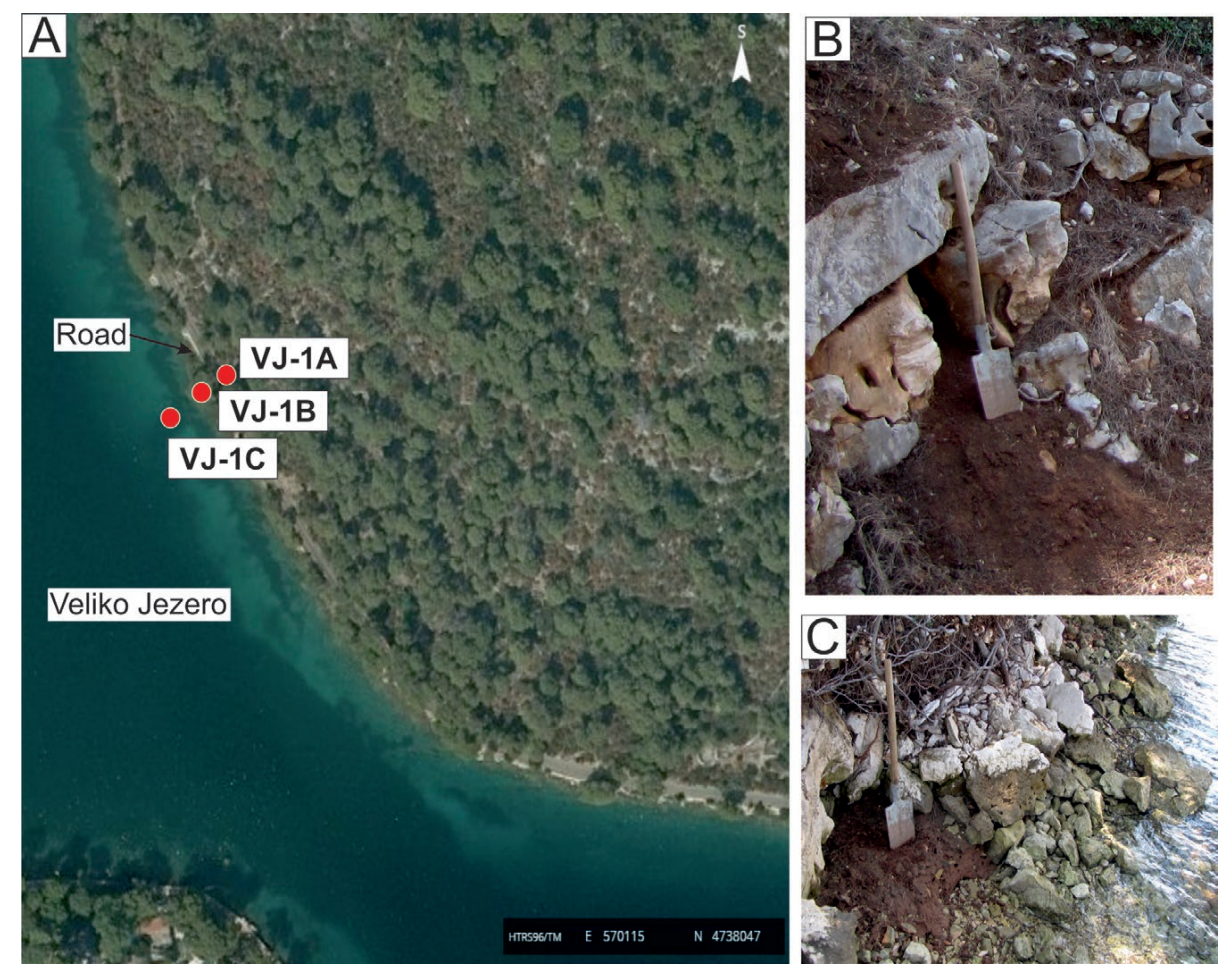

Figure 2. A) Larger area of seashore intertidal sampling locations displayed in Figure 1 (source: https://geoportal.dgu.hr/); B) Calcocambisol soil; C) colluvium. 
Different binding sites of trace metals in samples were analyzed by sequential extraction. A series of reagents were used to extract operationally-defined phases (selectivity depends on factors such as chemicals used, time and nature of contact, and the sample to volume ratio) in a defined sequence from $1 \mathrm{~g}$ of the sample. A sequential extraction scheme was used according to the European Community Bureau of Reference BCR (URE et al., 1993), which gave four fractions: acid (bound to carbonates - CC), reducible (bound to iron and manganese oxides, hydroxides and oxyhydroxides - FEMN), oxidizable (bound to organic matter and/or sulphides - OR) and residual (total dissolving using aqua regia - RES). The sequential extraction was performed in centrifuge tubes (polyethylene, $50 \mathrm{ml}$ ). Between each successive extraction step, the liquid phase was separated by centrifugation at $3000 \mathrm{rpm}$ for 10 minutes. All reagents used in the extraction procedures were of analytical grade. The resulting solutions were analyzed by flame atomic absorption spectrometry (AAnalyst 700, Perkin Elmer). The chemical composition of the samples was determined using the commercial ACME Analytical Laboratory. Major oxides were determined using an X-ray fluorescence spectrometer (XRF) following $\mathrm{LiBO}_{2}$ fusion.

In order to characterize the Calcocambisol/colluvium/marine lake sediment geochemically, the CIA, and the molecular ratio of selected elements (Ti/Al, $\mathrm{Al} / \mathrm{Si}, \mathrm{Ba} / \mathrm{Sr}, \mathrm{Sm} / \mathrm{Nd}, \Sigma$ Base $(\mathrm{Ca}, \mathrm{Mg}, \mathrm{Na}, \mathrm{K}) / \mathrm{Al}, \Sigma$ Base $(\mathrm{Ca}, \mathrm{Mg}, \mathrm{Na}, \mathrm{K}) / \mathrm{Ti}$ ) were used according to SHELDON \& TABOR (2009).

\section{RESULTS AND DISCUSSION}

\subsection{Physico-chemical properties of the analyzed samples}

All the analyzed samples showed a moderately alkaline reaction $\left(\mathrm{pH}_{\mathrm{H} 2 \mathrm{O}}\right)$, while $\mathrm{pH}_{\mathrm{KCl}}$ steadily increased from Calcocambisol (7.09) to marine lake sediment (8.17) (Table 1). Similar values of
$\mathrm{pH}_{\mathrm{H} 2 \mathrm{O}}$ and $\mathrm{pH}_{\mathrm{KCl}}$ were expected in marine lake sediment because it contains pore water with a high $\mathrm{NaCl}$ content, which affects the $\mathrm{pH}_{\mathrm{H} 2 \mathrm{O}}$ measurement (both $\mathrm{NaCl}$ and $\mathrm{KCl}$ are neutral salts). Marine lake sediment was enriched in carbonates (Table 1). Compared to the Calcocambisol (0.6 wt.\%), the colluvium showed a slightly higher proportion of carbonates $(0.8 \mathrm{wt} . \%)$. The highest organic matter $(\mathrm{OM})$ content $(0.6 \mathrm{wt} . \%)$ was observed in the marine lake sediment and the lowest value $(0.1 \mathrm{wt} . \%)$ was found in the colluvium sample (Table 1). Electrical conductivity (EC) increased rapidly from Calcocambisol to marine lake sediment (Table 1). The colluvium sample was collected on location in contact with the Veliko Jezero (Fig. 2C), and occasional flooding during high tides from the marine lake occurs at this site. Accordingly, marine salt water is the major carrier of ions responsible for the higher $\mathrm{EC}$ values in the colluvium sample. The highest $\mathrm{EC}$ value was determined in the marine lake sediment (Table 1). This is also an effect of salt water which is confirmed by the determination of halite in marine lake sediment (Table 3). Apart from salt water, the highest value of EC can be explained with the leaching and weathering process of $\Sigma \mathrm{Base} / \mathrm{Al}$ (Table 5) from Calcocambisol and its accumulation in marine lake sediment.

The $\mathrm{Fe}_{\mathrm{d}} / \mathrm{Fe}_{\mathrm{t}}$ ratio (which is taken as an index of weathering, e.g. BECH et al., 1997) in Calcocambisol and colluvium is 0.6 and 0.54 , respectively, and reflects a moderate degree of weathering of Fe-containing primary silicates (Table 1). Low values of $\mathrm{Fe}_{o}$ and the $\mathrm{Fe}_{\mathrm{o}} / \mathrm{Fe}_{\mathrm{d}}$ ratio in Calcocambisol and colluvium (Table 1) indicate the low content of poorly crystalline Fe oxides in these samples. In contrast, the marine lake sediment was relatively enriched in poorly crystallized Fe oxides $\left(\mathrm{Fe}_{\mathrm{o}} / \mathrm{Fe}_{\mathrm{d}}\right.$ is 0.4$)$ compared to the Calcocambisol and colluvium samples. Reverse trends were observed for poorly and well-crystallized Mn phases (Table 1). Both the light brownish-grey colour of the marine lake sediment (Table 2) and the low $\mathrm{Fe}_{\mathrm{d}} / \mathrm{Fe}_{\mathrm{t}}$ ratio (Table 1) clearly indicate that

Table 1. Soil/colluvium and sediment physical and chemical characteristics. Legend: EC- electrical conductivity ( $\mu \mathrm{S} / \mathrm{cm}), \mathrm{OM}$ - organic matter (wt. \%), CaCO 3 - carbonate content (wt. \%), $\mathrm{Fe}_{\mathrm{d}}$ - iron extractable with Na dithionite-citrate bicarbonate (wt. \%), Mn $\mathrm{d}_{\mathrm{d}}$-manganese extractable with Na dithionite-citrate bicarbonate (mg/kg), $\mathrm{Fe}_{\mathrm{o}}$ - iron extractable with ammonium oxalate (wt. \%), $\mathrm{Mn}_{\mathrm{o}}$ - manganese extractable with ammonium oxalate (mg/kg), Fe $\mathrm{t}^{-}$total content of iron (wt. \%).

\begin{tabular}{|c|c|c|c|c|c|c|c|c|c|c|c|c|c|}
\hline Material & $\mathrm{pH}_{\mathrm{H} 2 \mathrm{O}}$ & $\mathrm{pH}_{\mathrm{KCl}}$ & EC & $\mathrm{CaCO}_{3}$ & $\mathrm{OM}$ & $\mathrm{Fe}_{\mathrm{t}}$ & $\mathrm{Fe}_{\mathrm{d}}$ & $\mathrm{Fe}_{\mathrm{o}}$ & $\mathrm{Mn}_{\mathrm{d}}$ & $\mathrm{Mn}_{\circ}$ & $\mathrm{Fe}_{\mathrm{o}} / \mathrm{Fe}_{\mathrm{d}}$ & $M n_{o} / M_{d}$ & $\mathrm{Fe}_{\mathrm{d}} / \mathrm{Fe}_{\mathrm{t}}$ \\
\hline Calcocambisol & 8.20 & 7.09 & 256 & 0.564 & 0.1 & 5.48 & 3.29 & 0.14 & 529 & 440 & 0.04 & 0.83 & 0.6 \\
\hline Colluvium & 8.07 & 7.67 & 7513 & 0.846 & 0.07 & 5.34 & 2.87 & 0.19 & 713 & 697 & 0.07 & 0.98 & 0.54 \\
\hline
\end{tabular}

Table 2. Physical characteristics of analyzed samples.

\begin{tabular}{|c|c|c|c|c|c|}
\hline $\begin{array}{l}\text { Color (MUNSELL SOIL COLOR } \\
\text { CHART, 1994) }\end{array}$ & Material & $\begin{array}{c}\text { Sand } \\
2-0.063 \mathrm{~mm}(\%)\end{array}$ & $\begin{array}{c}\text { Silt } \\
0.063-0.002 \mathrm{~mm}(\%)\end{array}$ & $\begin{array}{c}\text { Clay } \\
<0.002 \mathrm{~mm}(\%)\end{array}$ & $\begin{array}{c}\text { Texture } \\
\text { (SOIL SCIENCE DIVISION STAFF, 2017) }\end{array}$ \\
\hline $2.5 Y R$ 4/4 reddish brown & Calcocambisol & 6.68 & 61.50 & 31.82 & clayey silt \\
\hline 10 YR 4/4 brown & Colluvium & 6.72 & 58.54 & 34.74 & clayey silt \\
\hline 2.5 Y $6 / 2$ lightly brownish grey & Marine lake sediment & 47.85 & 42.68 & 9.47 & silty sand \\
\hline
\end{tabular}

Table 3. Semi-quantitative mineral composition of the $<2 \mathrm{~mm}$ fraction (based on the analysis of $<2 \mathrm{~mm},<2 \mu \mathrm{m}$ and $<1 \mu \mathrm{m}$ fractions). HI: Halite. Cal: Calcite. Cal 2: Mg Calcite. Arg: Aragonite. Dol: Dolomite. Qtz: Quartz. Pl: Plagioclase. Kfs: Potassium feldspar. Amp: Amphibole. Gt: Goethite. Hem: Hematite. Py: Pyrite. M: Micaceous minerals (mica and illitic material). Kln: Kaolinite. Chl: Chlorite. 14Å: Smectite and/or vermiculite. MLCM: Mixed-layer clay minerals in which type of interstratification and constituting clay minerals were not recognized with certainty. AM: Amorphous matter.

\begin{tabular}{|c|c|c|c|c|c|c|c|c|c|c|c|c|c|c|c|c|c|c|}
\hline Material & $\mathrm{HI}(\%)$ & $\begin{array}{l}\text { Cal } \\
(\%)\end{array}$ & $\begin{array}{c}\text { Cal } 2 \\
(\%)\end{array}$ & $\begin{array}{l}\text { Arg } \\
(\%)\end{array}$ & $\begin{array}{l}\text { Dol } \\
(\%)\end{array}$ & $\begin{array}{l}\text { Qtz } \\
(\%)\end{array}$ & $\begin{array}{c}\mathrm{PI} \\
(\%)\end{array}$ & Kfs & Amp & $\mathrm{Gt}$ & Hem & Py & M & $\mathrm{Kln}$ & Chl & $14 \AA$ & MLCM & AM \\
\hline Calcocambisol & - & $?$ & - & - & - & 13 & 2 & $x$ & $x$ & $x$ & $x$ & - & $x x x$ & $x x$ & - & $?$ & $x x$ & $\mathrm{x}$ \\
\hline Colluvium & - & 1 & - & - & 1 & 14 & 3 & $x$ & - & $x$ & $x$ & - & $x x x$ & $x x$ & - & $?$ & $x x x$ & $x$ \\
\hline Marine lake sediment & 2 & 35 & 7 & 39 & 8 & $x$ & $x$ & $x$ & $x$ & $?$ & $?$ & $x$ & $\mathrm{x}$ & $x$ & $x$ & $?$ & $x$ & $x$ \\
\hline
\end{tabular}

" $\mathrm{x}$ " relative abundance of minerals based on $\mathrm{X}$-ray diffraction (no quantitative value is assigned to $\mathrm{x}$ ).

"?" mineral phase was not detected with certainty. 
Table 4. Mineral composition of the < $2 \mu \mathrm{m}$ fraction of Calcocambisol, colluvium and insoluble residue of the marine lake sediment, respectively. III: Illitic material. For other abbreviations see Table 3.

\begin{tabular}{|c|c|c|c|c|c|c|c|c|c|c|c|}
\hline Material & Qtz & $\mathrm{PI}$ & $\mathrm{Gt}$ & Hem & Py & III & Kln & Chl & $14 \AA$ & MLCM & AM \\
\hline Calcocambisol & $x$ & - & $x$ & $x$ & - & $x x x$ & $x x$ & - & $?$ & $x x$ & $x x$ \\
\hline Colluvium & $\mathrm{x}$ & $?$ & $\mathrm{x}$ & $x$ & - & $x x x$ & $x x$ & - & $?$ & $x x x$ & $x x$ \\
\hline Marine lake sediment & $x$ & - & $?$ & $?$ & $x$ & $x x x$ & $x x$ & $x x$ & $?$ & $x$ & $x$ \\
\hline
\end{tabular}

Table 5. Ratios of analyzed chemical indicators.

\begin{tabular}{|c|c|c|c|c|c|c|c|}
\hline Material & $\mathrm{Al} / \mathrm{Si}$ & Ti/Al & $\Sigma$ Base/Al & $\Sigma$ Base/Ti & $\mathrm{CIA}$ & $\mathrm{Ba} / \mathrm{Sr}$ & $\mathrm{Sm} / \mathrm{Nd}$ \\
\hline Calcocambisol & 0.24 & 0.06 & 0.49 & 3.20 & 77.51 & 3.36 & 0.1832 \\
\hline Colluvium & 0.24 & 0.06 & 0.65 & 4.29 & $72.13^{a}$ & 1.97 & 0.1833 \\
\hline Marine lake sediment & 0.20 & 0.07 & 19.85 & 14.86 & $5.04^{\mathrm{a}}$ & 0.04 & 0.1750 \\
\hline
\end{tabular}

$\mathrm{CIA}=$ Chemical Index of Alteration calculated as $\mathrm{Al}^{\mathrm{a}} 100 /(\mathrm{Al}+\mathrm{Ca}+\mathrm{K}+\mathrm{Na})$.

a -sample contains calcite and dolomite.
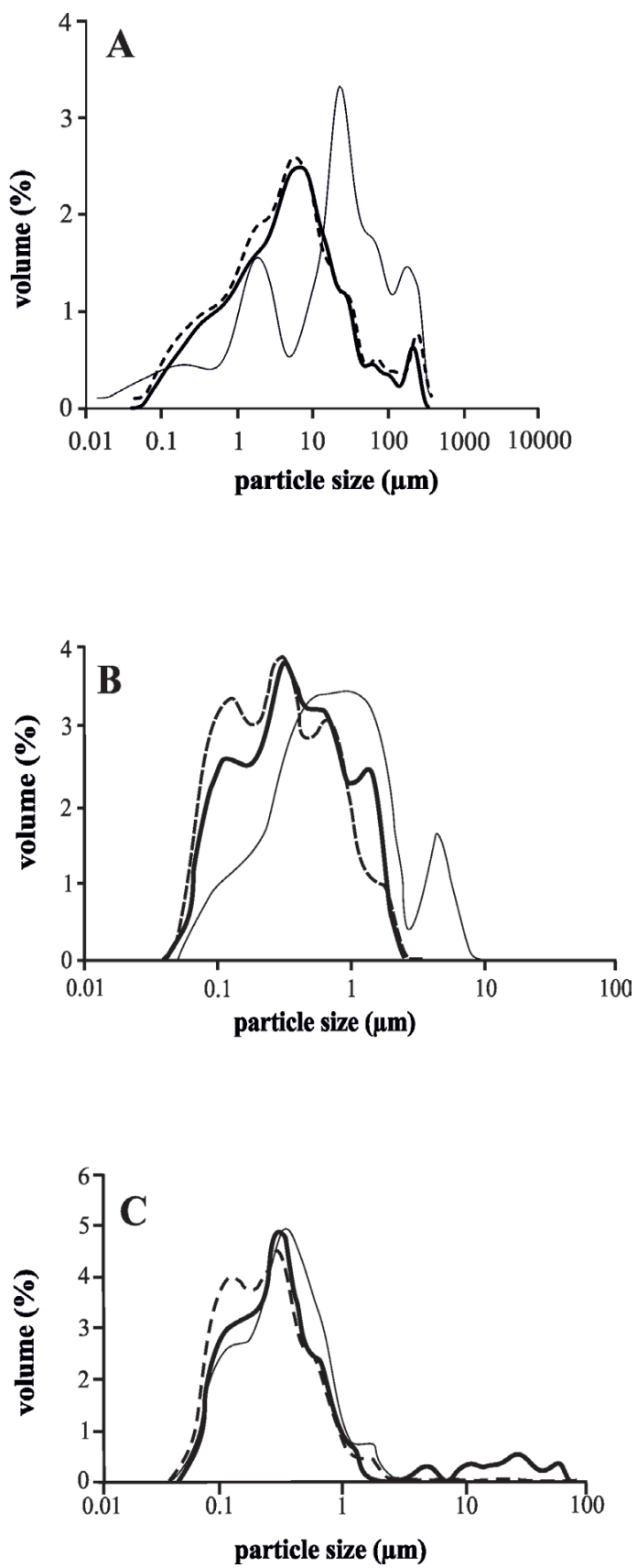

Figure 3. Particle-size distribution of $(A)$ original samples $(<2 \mathrm{~mm}),(B)$ original samples $(<2 \mu \mathrm{m})$ and $(C)$ original samples $(<1 \mu \mathrm{m})$. Legend: Calcocambisol $(-)$, colluvium (- - ), marine lake sediment ( - ). this sediment is depleted in Fe oxides and hydroxides compared to the Calcocambisol and colluvium samples.

The colour of the samples varied from reddish-brown (Calcocambisol) to brown (colluvium) to a light brownish grey (marine lake sediment) (Table 2). According to SOIL SCIENCE DIVISION STAFF (2017) Calcocambisol and colluvium are clayey silt, while marine lake sediment is silty sand (Table 2).

The particle size distribution (PSD) curves for the native soil and sediment samples and their fractions of less than 2 and $1 \mu \mathrm{m}$ are shown in Figure 3. The native Calcocambisol and colluvium show identical PSD curves, indicating the presence of the clay and clayey silt fractions with an average particle size of $18 \mu \mathrm{m}$ (Fig. 3A). In contrast, the marine lake sediment contains larger particles (sand and clayey silt fraction) with an average particle size of $131 \mu \mathrm{m}$. The fraction of soils $<2 \mu \mathrm{m}$ shows comparable PSD curves (average sizes 0.5 and $0.4 \mu \mathrm{m}$ ), while the PDS curve for the marine lake sediment shows the presence of larger particles (average size $1.2 \mu \mathrm{m})$ (Fig. 3B). The smallest fraction $(<1$ $\mu \mathrm{m})$ of all samples has similar PSD curves, indicating the presence of a predominantly submicron-sized fraction (Fig. 3C).

\subsection{Mineral composition of the analyzed samples}

Both the bulk and clay mineral compositions of the Calcocambisol and colluvium are very similar (Tables 3 and 4; Figs. 4 and 5). The main mineral phases in the Calcocambisol and colluvium are phyllosilicates and quartz. Plagioclase, K-feldspar, and Fe-oxides (goethite and hematite) were determined as minor mineral phases. Amphibole was detected as a minor phase only in the Calcocambisol. Colluvium contains calcite and dolomite as minor components. These mineral phases are derived from limestone and dolomite fragments incorporated in the colluvium situated on the lower parts of the slopes along the lakeshore. The main mineral phases in the clay fraction are illitic material, kaolinites, and a mixed-layer clay mineral (MLCM), in which the type of the interstratification and the constituent clay minerals were not recognized with certainty (Table 4). Quartz, hematite, and goethite are the minor mineral phases in this fraction. Both samples also contain amorphous matter.

Aragonite and calcite are major constituents, $\mathrm{Mg}$-calcite, and dolomite subordinate while halite, quartz, plagioclase, K-feldspar, amphibole, pyrite, and phyllosilicates are minor mineral phases in the marine lake sediment (Table 3, Fig. 6). Since this sample is rich in carbonates, it was necessary to analyze the carbonate-free residue to compare the non-carbonate components of the marine lake sediment with the Calcocambisol and the collu- 


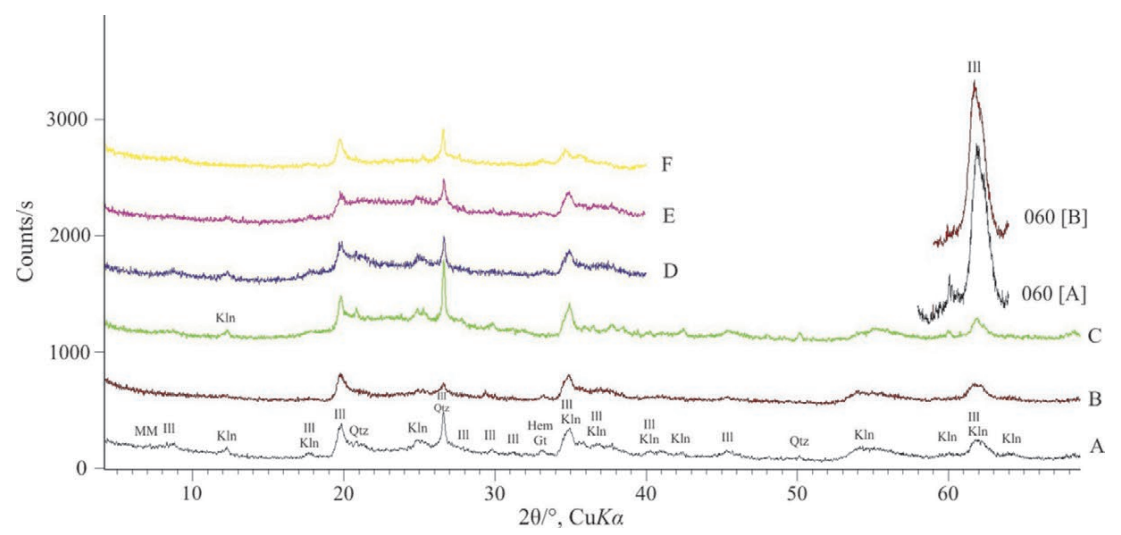

Figure 4. X-ray diffractograms of clay fractions $(<2 \mu \mathrm{m}$ and $<1 \mu \mathrm{m})$ (A-F) of the Calcocambisol, A-untreated clay fraction $(<2 \mu \mathrm{m})$ with difraction line 060 [A], Buntreated clay fractions $(<1 \mu \mathrm{m})$ with difraction line $060[\mathrm{~B}], \mathrm{C}$ - treated clay fraction $(<2 \mu \mathrm{m}) 24$ hours with $\mathrm{HCl}(1: 1), \mathrm{D}$ - clay fraction $(<2 \mu \mathrm{m})$ glycerol solvated, E- clay fraction $(<2 \mu \mathrm{m})$ ethylene glycol solvated, F- clay fraction $(<2 \mu \mathrm{m})$ heated for 2 hours at $650^{\circ} \mathrm{C}$.

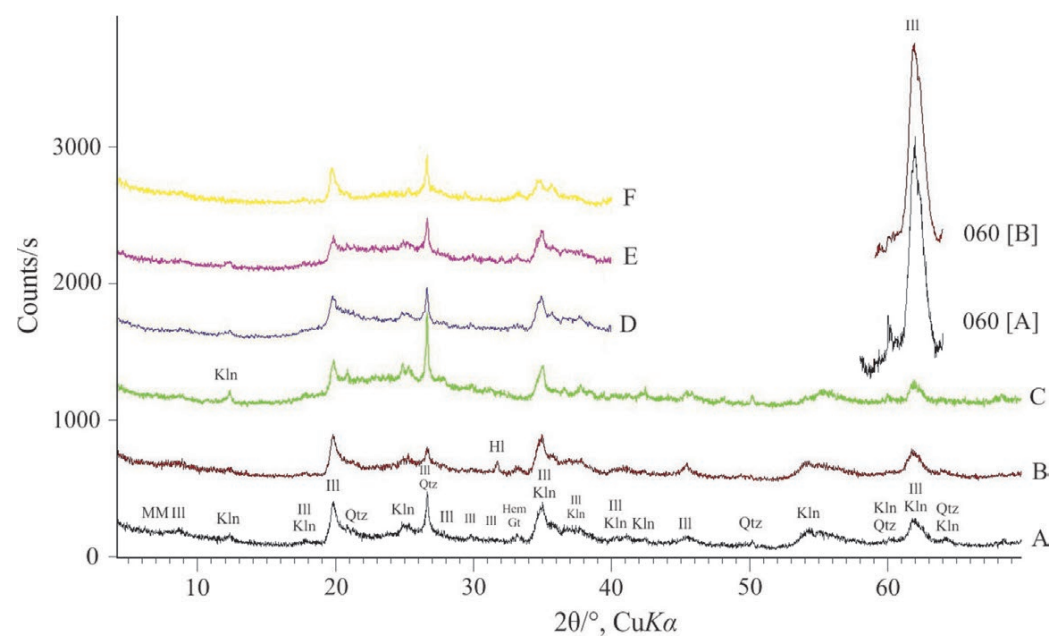

Figure 5. X-ray diffractograms of clay fractions $(<2 \mu \mathrm{m}$ and $<1 \mu \mathrm{m})(\mathrm{A}-\mathrm{F})$ of the colluvium, A-untreated clay fraction $(<2 \mu \mathrm{m})$ with difraction line $060[\mathrm{~A}], \mathrm{B}-\mathrm{untreat}-$ ed clay fractions $(<1 \mu \mathrm{m})$ with difraction line $060[\mathrm{~B}], \mathrm{C}$ - treated clay fraction $(<2 \mu \mathrm{m}) 24$ hours with $\mathrm{HCl}(1: 1)$, D- clay fraction $(<2 \mu \mathrm{m})$ glycerol solvated, E- clay fraction $(<2 \mu \mathrm{m})$ ethylene glycol solvated, F- clay fraction $(<2 \mu \mathrm{m})$ heated for 2 hours at $650^{\circ} \mathrm{C}$.

vium samples (Table 4). The main mineral phases in the carbonate-free clay fraction of the marine lake sediment are illitic material and kaolinites (both the poorly- and well-crystallized kaolinite were determined). These minerals were also determined as the main constituents in the clay fraction of Calcocambisol and colluvium. Compared to the Calcocambisol and colluvium, the carbonate-free clay fraction of the marine lake sediment contained pyrite and chlorite. It is important to point out that MLCM, which occurs along with illite and kaolinite as the main mineral phase in the clay fraction of Calcocambisol and colluvium, was also determined in the clay fraction of the marine lake sediment, but as a subordinate mineral phase.

The bulk mineralogy of the studied marine lake sediment (Table 3, Fig. 6) agrees with the results previously obtained by SONDI \& JURAČIĆ (2010) and SONDI et al. (2017). They found that the authigenic formation of aragonite is the main source of sedimentary material in the Mljet Lakes, Mg-calcite is the product of biomineralization, while calcite and dolomite originate from the surrounding carbonate rocks. The occurrence of aragonite is significant and is a consequence of its authigenic formation in the aquatic system during the whiting events (SONDI \& JURAČIĆ, 2010). They also documented that the increased concentration of strontium in the recent sediment of the Mljet Lakes is an indicator of authigenic aragonite formation. According to SONDI et al. (2017), the formation of aragonite in the Mljet Lakes has been a continuous process over several hundred years. We found pyrite in both $<2 \mathrm{~mm}$ and $<2 \mu \mathrm{m}$ fractions. This mineral phase indicates occasional events of oxygen deficiency in the lake system. Indeed, IVANIĆ et al. (2020) determined micron-sized early-diagenetic framboidal pyrite in sediments from the Malo Jezero (Fig. 1A). They also analyzed the mineral composition of the clay fraction of the sediment from Malo Jezero and discovered that illite and kaolinites were the main phyllosilicate phases, while MLCMs were determined as a minor mineral component. They concluded that the input of terrigenous material into the lake system is limited to soil erosion and aeolian deposition. In addition to illite, kaolinites and MLCM in the marine lake sediment from Veliko Jezero we also detected chlorite (Table 4). It is important to note that this mineral phase was not detected in either the Calcocambisol or colluvium (Table 4).

Dominant mineral phases in the $<2 \mu \mathrm{m}$ fraction of Calcocambisol and colluvium are comparable to the dominant mineral phases found in the clay fraction of Calcocambisol samples from Istria. DURN et al. (2019) found that kaolinites (both the poorlyand well-crystallized kaolinite) and illitic material are the dominant clay mineral phases in the Calcocambisol sample from Istria, while the main mineral phases in the clay fraction of Calcocambisol and colluvium are illitic material, kaolinites and MLCM. We presume that MLCM probably formed as a result of chlorite destabilization during pedogenesis, a process already observed 


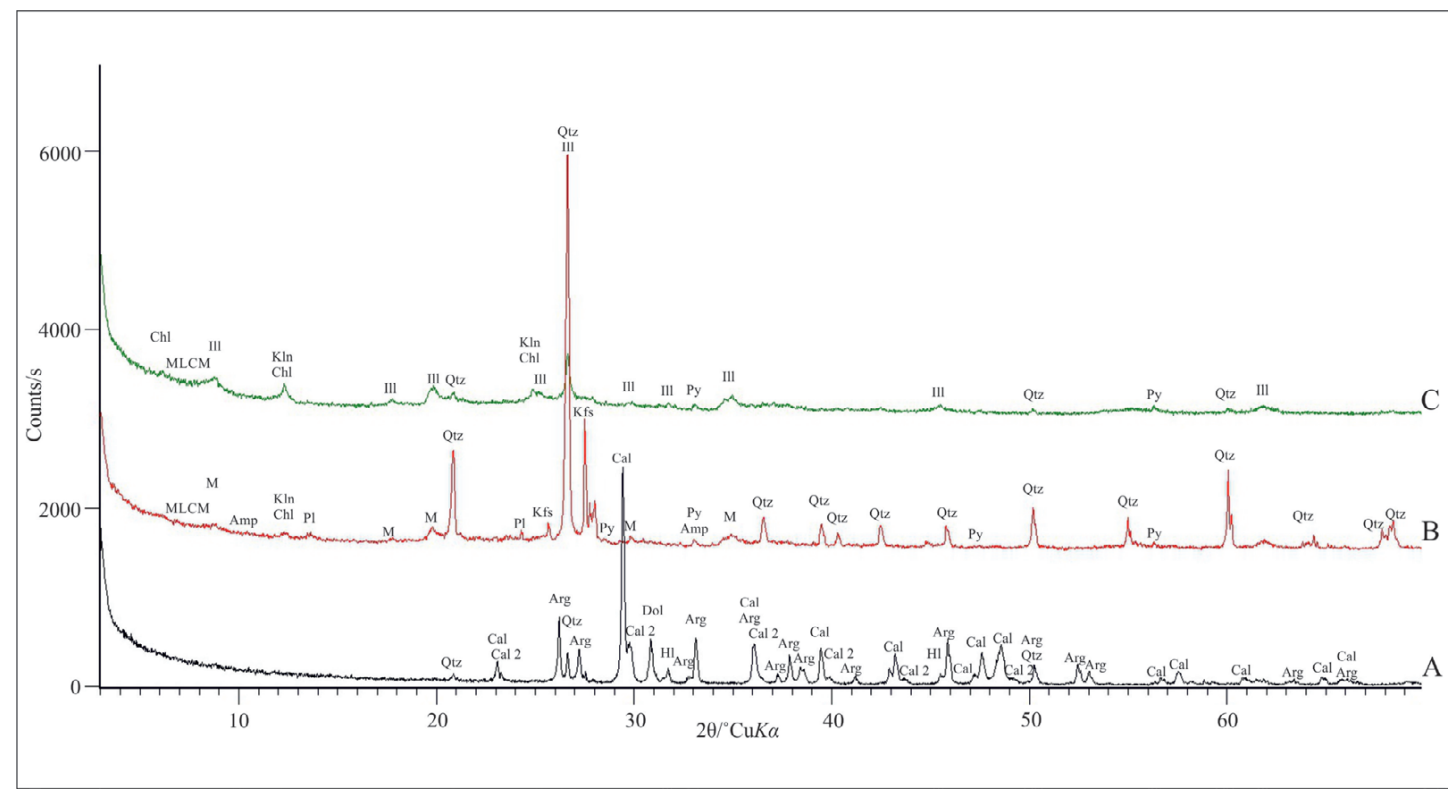

Figure 6. X-ray diffractograms of bulk sample (A-B) and clay fractions (C) of the marine lake sediment from Veliko Jezero A-untreated, B-treated with pH 4.5 NaHAc/ Ac pufer, C-untreated sample with clay fraction $<2 \mu \mathrm{m}$. For abbreviations see Tables 3 and 4.
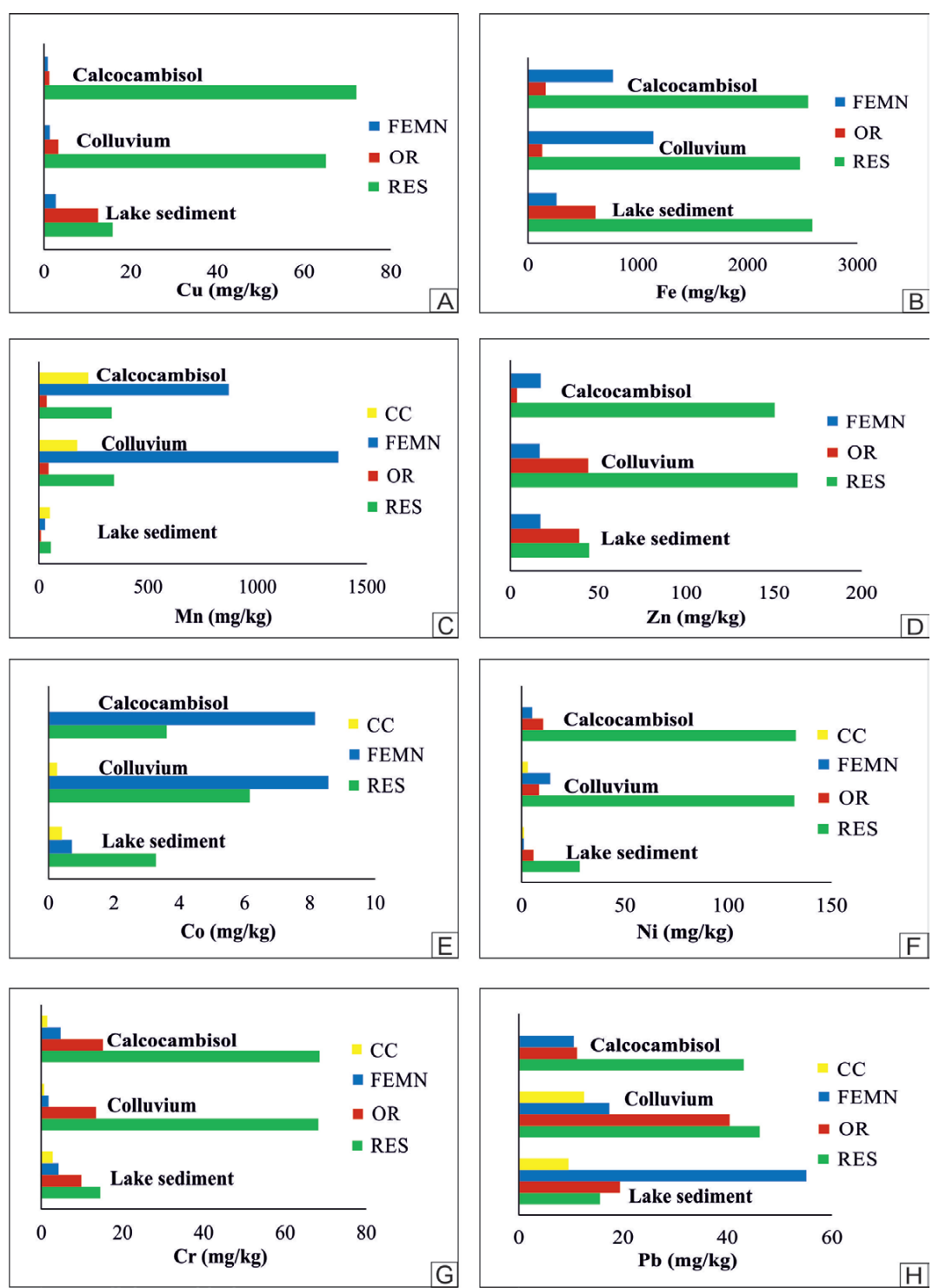

Figure 7. Distribution of trace elements in the analyzed samples. A) $\mathrm{Cu}$; B) Fe; C) Mn; D) Zn; E) Co; F) Ni; G) Cr; H) Pb. Units are in mg/kg. Legend: CC- bound to carbonates, FEMN- bound to iron and manganese oxides, hydroxides and oxyhydroxides, OR- bound to organic matter and/or sulphides and RES- residual (total dissolving using aquaregia). 
in the formation of mixed-layer chlorite vermiculite in Pseudogley on loess in the Pannonian region of Croatia (RUBINIĆ et al., 2015) and in polygenetic soil on Late Glacial Loess at Susak Island (DURN et al., 2018).

The presence of amphibole in Calcocambisol indicates that its parent material can mostly be derived from aeolian sands deposited on the SE part of Mljet Island rather than from the insoluble residue of limestone and dolomite. Namely, PAVELIĆ et al. (2014) found amphiboles in aeolian deposits on the Central Adriatic islands. They determined that the amphiboles were formed by the weathering processes of various metamorphic and magmatic rocks originating from the Inner Dinarides, which were transported to the coastal belt by the palaeo-Neretva River during glacial sea-level subsidence when the Central Adriatic islands were part of the mainland. During the interglacials and interstadials in the Pleistocene, the aeolian deposits found on the coast and on the islands along the Adriatic Sea were exposed to soil-forming processes. Therefore, thin aeolian sediments situated on limestones and dolomites might have contributed to the soil parent material.

Based on the mineral composition, we can conclude that the noncarbonate fraction of the marine lake sediment originates from weathering and erosion of the surrounding soils and colluvium (quartz, feldspars, and phyllosilicates), authigenesis (appearance of early-diagenetic pyrite) and probably direct aeolian deposition of mineral components into the marine lake (amphibole could be derived from local soils and/or direct aeolian input). The observed difference between the phyllosilicate mineral phases in the clay fraction of Calcocambisol/colluvium and the carbonate free clay fraction of the marine lake sediment is related to 1) the presence of chlorite in the marine lake sediment and 2) the higher content of MLCM in the Calcocambisol/colluvium. We tentatively propose that the chlorite in the marine lake sediment was inherited from Calcocambisol/colluvium as a result of soil erosion prior to complete chlorite destabilization in the soil. The higher share of MLCM in Calcocambisol/colluvium compared to marine lake sediment supports this proposal. The absence of chlorite in the sediment from Malo Jezero (IVANIĆ et al., 2020) is probably the result of local soil distribution/erosion and the fact that the marine lake sediment in this study was sampled closer to the lake shore, whereas in the case of Malo Jezero the sediment was sampled in the deeper part of the lake.

\subsection{Sequential chemical extraction results}

In this study, sequential extraction analyses were applied to determine the diverse distribution of trace elements in sequenced fractions of the investigated Calcocambisol/colluvium and marine lake sediment (Fig. 7).

Trace elements in soils are partitioned between the different phases present, i.e. organic matter, oxyhydroxides of iron and manganese, sulphides, clay minerals, and are retained on these solid phases by different mechanisms, i.e. ion exchange, complexation, precipitation or co-precipitation (BENEDETTI et al., 1995; NEMATI et al., 2011), or are retained in the lattice of soil minerals.

The partitioning of all analyzed elements among the fractions (CC, FEMN, OR, RES) is very similar for Calcocambisol and colluvium (Fig. 7). Different partitioning compared to the marine lake sediment was observed for $\mathrm{Mn}, \mathrm{Pb}$ and $\mathrm{Co}$ (Figs. 7C and $\mathrm{E}$ ). The content of $\mathrm{Cu}, \mathrm{Mn}, \mathrm{Zn}, \mathrm{Co}, \mathrm{Ni}$, and $\mathrm{Cr}$ is significantly lower in the marine lake sediment compared to Calcocambisol and colluvium, as this sample contains more than $70 \%$ carbonate mineral phases and consequently a lower share of clay minerals and $\mathrm{Fe}$ and $\mathrm{Mn}$ oxyhydroxides (Table 1). The relatively low con- centrations of $\mathrm{Mn}, \mathrm{Co}, \mathrm{Ni}, \mathrm{Pb}$ and $\mathrm{Cr}$ (Fig. 7) in all the analyzed samples were measured in the $\mathrm{CC}$ fraction.

The distribution of trace elements in the Calcocambisol/colluvium showed the highest concentrations of $\mathrm{Cu}, \mathrm{Fe}, \mathrm{Zn}, \mathrm{Ni}, \mathrm{Cr}$ and $\mathrm{Pb}$ in the RES fraction, while the highest concentrations of $\mathrm{Mn}$ and $\mathrm{Co}$ were present in the FEMN fraction (Figs. 7C, E). The manganese content in the FEMN fraction of Calcocambisol and colluvium also agrees well with the data for poorly and well-crystallized Mn phases (Table 1), clearly indicating that $\mathrm{Mn}$ is predominantly associated with Mn oxides. Cobalt is also classically associated with Mn oxides, which is confirmed by other studies (LATRILLE et al., 2001; PALUMBO et al., 2001; LIU et al., 2002; BRADL, 2004; CORNU et al., 2005). According to VODYANITSKII et al. (2009) in the formation of oxides in soils, Mn acts as an individual phase carrying metals such as $\mathrm{Cu}, \mathrm{Co}, \mathrm{Cr}$, $\mathrm{Ni}, \mathrm{Pb}$ and $\mathrm{Zn}$, which are associated with $\mathrm{Mn}$ oxides by coprecipitation and substitution. In many studies (GASPARATOS et al., 2005; NEAMAN et al., 2008), the distribution of Co in Fe$\mathrm{Mn}$ fine-grained soil aggregates follows that of $\mathrm{Mn}$. This accumulation of Co on soil particles is due to the oxidation of absorbed $\mathrm{Co}(\mathrm{II})$ to $\mathrm{Co}$ (III) on Mn oxides and their incorporation into the Mn oxide mineral structure.

Based on the distribution of trace elements in the marine lake sediment (Fig. 7), it can be concluded that the highest concentrations of all the analyzed elements (except $\mathrm{Pb}$ ) were determined in the RES fraction. The highest concentrations of $\mathrm{Pb}$ were present in the FEMN fraction (Fig. 7H). This can probably be explained by the formation of stable complexes between $\mathrm{Pb}$ and $\mathrm{Fe}$ oxyhydroxides. Other studies (IP et al., 2007; ROGAN ŠMUC et al., 2018) also confirmed a high bounding affinity of $\mathrm{Pb}$ to the reducible phase in marine sediments.

After the residual fraction, the FEMN fraction is the most Fe-rich fraction in Calcocambisol and colluvium (Fig. 7B). In contrast, in marine lake sediment, after the residual fraction, the OR fraction is enriched in Fe (Fig. 7B). Besides Fe, this fraction in the marine lake sediment is also enriched in $\mathrm{Pb}, \mathrm{Cr}, \mathrm{Ni}, \mathrm{Zn}$ and $\mathrm{Cu}$, which can probably be linked to sulphides (pyrite) and organic matter.

\subsection{Geochemical indicators of weathering}

For geochemical characterization of weathering, the molecular $\mathrm{Al} / \mathrm{Si}$ ratio, and the Chemical Index of Alteration (CIA) were used. Both indexes are considered to be measures for weathering and "clayness" (SHELDON \& TABOR, 2009), while the Ba/Sr, the $\Sigma$ Base $(\mathrm{Ca}, \mathrm{Mg}, \mathrm{Na}, \mathrm{K}) / \mathrm{Al}$ and the $\Sigma \mathrm{Base}(\mathrm{Ca}, \mathrm{Mg}, \mathrm{Na}, \mathrm{K}) / \mathrm{Ti}$ ratios represent the leaching behaviour during weathering processes (SHELDON, 2006). It was also established that the Ti/Al and $\mathrm{Sm} / \mathrm{Nd}$ ratios can be used as provenance indicators (SHELDON, 2006). The Al/Si ratio in both Calcocambisol and colluvium is the same (Table 5), which equally indicates processes of hydrolysis and the distribution of clay minerals.

PEREZ-HUERTA \& SHELDON (2006) used $\Sigma$ Base/Al for the exchangeable terrigenous input of nutrients in shallow marine systems derived from soils. According to the $\Sigma$ Base/Al and $\Sigma$ Base/ Ti ratios (Table 5), the colluvium is slightly enriched in basic cations, probably related to the presence of calcite and dolomite, which are accessory mineral phases in this sample (Table 3). Lower CIA and $\mathrm{Ba} / \mathrm{Sr}$ values in the colluvium are consistent with this statement (Tables 3 and 5). Both the $\Sigma$ Base/Al and $\Sigma$ Base/Ti ratios, show that the marine lake sediment is highly enriched in basic cations, which is a consequence of the presence of carbonate 
minerals, particularly aragonite, calcite and $\mathrm{Mg}$-calcite, which are the dominant mineral components in this sample (Table 3).

Very high CIA values in the Calcocambisol and colluvium clearly indicate intense weathering (Table 5). According to SHELDON \& TABOR (2009), the CIA is a measure of the weathering of feldspar minerals and their hydration during the formation of clay minerals. Accordingly, as the clay content increases, the $\mathrm{Al}$ concentration also increases, whereas the $\mathrm{Ca}, \mathrm{K}$, and $\mathrm{Na}$ content should decrease, resulting in higher CIA values. The CIA values obtained in this study are in general agreement with the mineral composition and particle size distribution of the analysed Calcocambisol and colluvium. The predominance of kaolinite and illite, the share of the clay fractions (Table 2) and a lower proportion of K-feldspar and plagioclase (Tables 3 and 4), confirmed the high CIA values in the Calcocambisol/colluvium (Table 5).

$\mathrm{The} \mathrm{Sm} / \mathrm{Nd}$ ratio indicates potential source materials, acidification, leaching, and weathering intensity and can be used in relatively stable pedogenic environments (SHELDON \& TA$\mathrm{BOR}, 2009)$. The $\mathrm{Sm} / \mathrm{Nd}$ ratio was slightly lower in the marine lake sediment compared to the Calcocambisol/colluvium samples (Table 5). The Ti/Al ratio is particularly useful as a provenance indicator because $\mathrm{Ti}$ contents may be quite variable among the different types of rocks (SHELDON \& TABOR, 2009). In addition, DURN et al. (2018) found that the Ti/Al ratio is also a good indicator of provenance for polygenetic soils formed on loess. The obtained results of the Ti/Al ratio for all the analyzed samples are almost the same (Table 5) with a slight increase for the marine lake sediment. This is in accordance with the mineral composition of the insoluble residue of the samples (Table 4), which is very similar except for pyrite and chlorite. Therefore, based on both the $\mathrm{Sm} / \mathrm{Nd}$ and $\mathrm{Ti} / \mathrm{Al}$ ratios, we can conclude that the aluminosilicate part of the Calcocambisol, colluvium and marine lake sediment is of the same provenance.

Based on the mineralogical and geochemical results, we concluded that the detrital parent material for the marine lake sediments of the Veliko Jezero are Calcocambisol and colluvium. According to SONDI et al. (2017), the detrital component of the first $50 \mathrm{~cm}$ of the sediment originates from the surrounding soil of the Veliko Jezero lake. Apart from weathering and erosion of the surrounding soils, direct aeolian deposition of detrital material into the marine lake cannot be neglected. The results of the mineralogical analyses of the marine lake sediment of Veliko Jezero showed the presence of amphibole, which may indicate an aeolian source of the material. Indeed, RAZUM et al. (2020) found that the recent detrital part of the medium to coarse silt and sand fraction material in Veliko Jezero comes from aeolian sands, which are rich in minerals derived from mafic and ultramafic magmatic rocks. These observations are also in agreement with the origin of Quaternary aeolian sands deposited on the southern sides of the Mljet Island and surrounding islands (BABIĆ et al., 2013; PAVELIĆ et al., 2014; KOVAČIĆ et al., 2018).

\section{CONCLUSIONS}

The results of this study provide insight into the particle size distribution (PSD), mineral composition, and geochemical characteristics of the Calcocambisol, colluvium, and recent marine lake sediment of the narrow intertidal seashore zone of the Veliko Jezero lake on Mljet Island. The fractions of Calcocambisol/colluvium $<2 \mathrm{~mm}$ and $<2 \mu \mathrm{m}$ show similar PSD curves compared to the marine lake sediment, which contains larger particles in these fractions. However, the smallest fraction $(<1 \mu \mathrm{m})$ of all analyzed materials have similar PSD curves implying the presence of a predominantly submicron-sized fraction with an average particle size less than $1 \mu \mathrm{m}$. Very high CIA values in Calcocambisol and colluvium clearly indicate their intense weathering. Based on both the $\mathrm{Sm} / \mathrm{Nd}$ and $\mathrm{Ti} / \mathrm{Al}$ ratios, we can conclude that the aluminosilicate part of the Calcocambisol, colluvium and marine lake sediment is of the same provenance. Both bulk and clay mineral compositions of the recent marine lake sediment revealed that the noncarbonate fraction originated from weathering of the surrounding soils and colluvium (e.g. illitic material, kaolinites, chlorite and mixed-layer clay minerals), authigenesis (early-diagenetic pyrite) and possibly direct aeolian deposition of mineral components to the marine lake (amphibole). The distribution of each analysed element among the sequential fractions is very similar in both the Calcocambisol and colluvium. Different partitioning in the Calcocambisol/colluvium compared to the marine lake sediment was observed for $\mathrm{Mn}, \mathrm{Co}$ and $\mathrm{Pb}$. The FEMN fraction is a major sink for Mn and $\mathrm{Co}$ in the Calcocambisol/colluvium and for $\mathrm{Pb}$ in the marine lake sediment respectively.

\section{ACKNOWLEDGEMENT}

This work has been fully supported by the Croatian Science Foundation under the project NanoMin (Grant No. 2504). We thank Prof. M. MILEUSNIĆ for her help during fieldwork and $\mathrm{N}$. TADEJ for suggestions during mineralogical analysis.

\section{REFERENCES}

BABIĆ, LJ., ZUPANIČ, J., VIDOVIĆ, J., RAZUM, I., LUŽAR-OBERITER, B. \& CRNJAKOVIĆ, M. (2013): Preservation of hanging aeolian deposits in insular karst depressions: sediment sources and implications for the Pleistocene palaeogeography of the SE Adriatic archipelago.-Aeolian Research, 11, 171-189. doi: 10.1016/j.aeolia.2013.06.003

BAKRAN-PETRICIOLI, T. \& PETRICIOLI, D. (2008): Habitats in submerged karst of Eastern Adriatic Coast - Croatian Natural Heritage.- Croatian Medical Journal, 49, 455-458. doi: 10.3325/cmj2008.4.455

BECH, J., RUSTULLET, J., GARIGO, J., TOBIAS, F.J. \& MARTINEZ, R. (1997): The iron content of some red Mediterranean soils from Northeast Spain and its pedogenic significance.- Catena, 28/3-4, 211-229. doi: 10.1016/S0341-8162(96)00039-2

BENEDETTI, M.F., MILNE, C.J., KINNIBURGH, D.G., VAN RIEMSDIJK, W.H. \& KOOPAL, L.K. (1995): Metal ion binding to humic substances: application of the non-ideal competitive adsorption model.- Environmental Science \& Technology, 29, 446-457. doi: 10.1021/es00002a022

BRADL, H.B. (2004): Adsorption of heavy metal ions on soils and soils constituents.- Journal of Colloid and Interface Science, 277/1, 1-18. doi: 10.1016/j.jcis.2004.04.005.

BRINDLEY, G.W. \& BROWN, G. (1980): Crystal structures of clay minerals and their X-ray identification.- Mineralogical Society, London, 495 p. doi: $10.1180 /$ mono-5

BROWN, G. (1961): The X-ray identification and crystal structures of clay minerals.-Mineralogical Society, London, $544 \mathrm{p}$.

BRUNOVIĆ, D., MIKO, S., ILIJANIĆ, N., PEH, Z., HASAN, O., KOLAR, T., ŠPARICA MIKO, M. \& RAZUM, I. (2019): Holocene foraminiferal and geochemical records in the coastal karst dolines of Cres Island, Croatia.- Geologica Croatica, 72/1, 19-42. doi: $10.4154 /$ gc. 2019.02

BURA-NAKIĆ, E., SONDI, I., MIKAC, N. \& ANDERSEN, M.B. (2020): Investigating the molybdenum and uranium redox proxies in a modern shallow anoxic carbonate rich marine sediment setting of the Malo Jezero (Mljet Lakes, Adriatic Sea).--Chemical Geology, 533, 119441. doi: 10.1016/j.chemgeo.2019.119441

CORNU, S., DESCHATRETTES, V., SALVADOR-BLANES, S., CLOZEL, B., HARDY, M., BRANCHUT, S. \& LE FORESTIER, L. (2005): Trace element accumulation in $\mathrm{Mn}-\mathrm{Fe}$ - oxide nodules of a planosolic horizon.- Geoderma, 125/1-5, 11-24. doi: 10.1016/j.geoderma.2004.06.009

CUCULIĆ, V., CUKROV, N., KWOKAL, Ž., STRMEČKI, S. \& PLAVŠIĆ, M. (2018): Assessing trace metal contamination and organic matter in the brackish lakes as the major source of potable water-- Environmental Geochemistry and Health, 40, 489-503. doi: 10.1007/s10653-017-9935-4

DURN, G., RUBINIĆ, V., WACHA, L., PATEKAR, M., FRECHEND, M., TSUKAMOTO, S., TADEJ, N. \& HUSNJAK, S. (2018): Polygenetic soil formation on Late Glacial Loess on the Susak Island reflects paleo-environmental changes in the Northern Adriatic area.-Quaternary International, 494, 236-247. doi: 10.1016/j.quaint.2017.06.072

DURN, G., ŠKAPIN, S.D., VDOVIĆ, N., RENNERT, T., OTTNER, F., RUŽIČIĆ, S., CUKROV, N. \& SONDI, I. (2019): Impact of iron oxides and soil organic matter on the surface physicochemical properties and aggregation of Terra Rossa and Calco- 
cambisol subsoil horizons from Istria (Croatia).-Catena, 183, 104184, doi:10.1016/j. catena.2019.104184

GASPARATOS, D., TARENIDIS, D., HAIDOUTI, C. \& OIKONOMOU, G. (2005): Microscopic structure of soil Fe-Mn nodules: environmental implications.- Environmental Chemistry Letters, 2, 175-178. doi: 10.1007/s10311-004-0092-5

GOVORČIN, D.P., JURAČIĆ, M., HORVATINČIĆ, N. \& ONOFRI, V. (2001): Holocene sedimentation in the Soline channel (Mljet Lakes, Adriatic sea).- Natura Croatica, $10 / 4,247-258$

GUŠIĆ, I., VELIĆ, I. \& SOKAČ, B. (1995): Geology of the Mljet Island.- In: DURBEIĆ, P. \& BENOVIĆ, A. (eds.): Proceedings of the symposium: Island of Mljet natural characteristics and social evaluation. Croatian Ecological Society, Zagreb, 35-53

IP, C.C.M., LI, X.D., ZHANG, G., WAI, O.W.H. \& LI, Y.S. (2007): Trace metal distribution in sediments of the Pearl River Estuary and the surrounding coastal area, South China.-Environmental Pollution, 147/2,311-323. doi: 10.1016/j.envpol.2006.06.028

ISO 10390 (2005): Soil quality-determination of pH.- International Organisation for Standardisation, Switzerland.

ISO 10693 (1995): Soil quality-determination of carbonate content-volumetric method.International Organisation for Standardisation, Switzerland.

ISO 11265 (1994): Soil quality - Determination of the specific electrical conductivity.International Organisation for Standardisation, Switzerland.

IVANIĆ, M., DURN, G., ŠKAPIN, S.D. \& SONDI, I. (2020): Size-related mineralogical and surface physicochemical properties of the mineral particles from the recent sediments of the Eastern Adriatic Sea.- Chemosphere, 249, 126531. doi: 10.1016/j. chemosphere.2020.126531

JURINA, I., IVANIĆ, M., VDOVIĆ, N., TROSKOT-ČORBIĆ, T., LOJEN, S., MIKAC, N. \& SONDI, I. (2015): Deposition of trace metals in sediments of the deltaic plain and adjacent coastal area (the Neretva River, Adriatic Sea).- Journal of Geochemical Exploration, 157, 120-131. doi: 10.1016/j.gexplo.2015.06.005

KAISER, K. \& GUGGENBERGER, G. (2003): Mineral surfaces and soil organic matter-European Journal of Soil Science, 54/2, 219-236. doi: 10.1046/j.1365-2389.2003. 00544.X

KALANTZI, I., SHIMMIELD, T.M., PERGANTIS, S.A., PAPAGEORGIOU, N., BLACK, K.D. \& KARAKASSIS, I. (2013): Heavy metals, trace elements and sediment geochemistry at four Mediterranean fish farms.-Science of The Total Environment, 444, 128-137. doi: 10.1016/j.scitotenv.2012.11.082

KALNEJAIS, L.H., MARTIN, W.R. \& BOTHNER, M.H. (2015): Porewater dynamics of silver, lead and copper in coastal sediments and implications for benthic metal fluxes.- Science of The Total Environment, 517, 178-194. doi: 10.1016/j.scitotenv.2015.02.011

KOROLIJA, B., BOROVIĆ, I., GRIMANI, I., MARINČIĆ, S., JAGAČIĆ, T., MAGAŠ, N. \& MILANOVIĆ, M. (1977): Osnovna geološka karta SFRJ, Tumač za listove Lastovo K 33-46, Korčula K 33-47 i Palagruža K 33-57 [Basic Geological Map of SFRY 1:100000, Geology of the Lastovo, Korčula, Palagruža sheets - in Croatian].Geološki Zavod Zagreb, Savezni Geološki Zavod, Beograd, 53p.

KOVAČIĆ, M., PAVELIĆ, D., VLAHOVIĆ, I., MARKOVIĆ, F., WACHA, L., KAMPIĆ, Š., RONČEVIĆ, S. \& DREMPETIĆ, D. (2018): Pleistocene alluvial and aeolian deposits with tephra on the island of Lopud (eastern mid Adriatic, Croatia): provenance, wind regime, and climate controls.- Quaternary International, 494, 92-104. doi: 10.1016/j.quaint.2017.11.054

LATRILLE, C., ELSASS, F., VAN OORT, F. \& DENAIX, L. (2001): Physical speciation of trace metals in Fe-Mn concretions from a rendzic lithosol developed on Sinemurian limestones (France).- Geoderma, 100/1-2,127-146. doi: 10.1016/S00167061(00)00083-5

LIU, F., COLOMBO, C., ADAMO, P., HE, J.Z. \& VIOLANTE, A. (2002): Trace elements in manganese-iron nodules from a Chinese Alfisol.- Soil Science Society of America Journal, 66, 661-670. doi: 10.2136/sssaj2002.6610

MARTINOVIĆ, J. (1982): Pedološka karta SFRJ mjerilo 1:50 000, list Mljet 1 [Pedological Map of SFRY 1:50000, Mljet sheet - in Croatian].- Projekt i savjet za izradu pedološke karte SR Hrvatske, Zagreb.

MEHRA, O.P. \& JACKSON, M.L. (1960): Iron oxide removal from soils and clays by a dithionite-citrate system buffered with sodium bicarbonate.-Clays Clay Minerals, 7 , 317-327. doi: 10.1016/B978-0-08-009235-5.50026-7

MOORE, D.M. \& REYNOLDS, R.C. (1989): X-ray diffraction and the identification and analysis of clay minerals.- Oxford University Press, Inc.,New York, $332 \mathrm{p}$

MORELLI, G., GASPARON, M., FIERRO, D., HU,W.P. \& ZAWADZKI, A. (2012): Historical trends in trace metal and sediment accumulation in intertidal sediments of Moreton Bay, southeast Queensland, Australia.- Chemical Geology, 300-301, 152-164. doi: 10.1016/j.chemgeo.2012.01.023

MUNSELL SOIL COLOR CHARTS (1994): Macbeth Division of Kollmorgen Instruments.- New Windsor, New York, USA.
NEAMAN, A., MARTINEZ, C.E., TROLARD, F. \& BOURRIE, G. (2008): Trace elements associations with Fe-Mn oxides in soil nodules: comparison of selective dissolution with electron probe microanalysis.- Applied Geochemistry, 23, 778-782. doi: 10.1016/j.apgeochem.2007.12.025

NEMATI, K., ABU BAKAR, N.K., RADZI ABAS, M. \& SOBHANZADEH, E. (2011): Speciation of heavy metals by modified BCR sequential extraction procedure in different depths of sediments from Sungai Buloh, Selangor, Malaysia.- Journal of Hazardous Materials, 192/1, 402-410. doi: 10.1016/j.jhazmat.2011.05.039

PALUMBO, B., BELLANCA, A., NERI, R. \& ROE, M.J. (2001): Trace metal partitioning in Fe-Mn nodules from Sicilian soils, Italy.- Chemical Geology, 173/4, 257-269. doi: 10.1016/S0009-2541(00)00284-9

PAVELIĆ, D., KOVAČIĆ, M., VLAHOVIĆ, I., MANDIĆ,O., MARKOVIĆ, F. \& WACHA, L. (2014): Topography controlling the wind regime on the karstic coast: late Pleistocene coastal calcareous sands of eastern mid-Adriatic, Croatia.- Facies 60/4, 843-863. doi: 10.1007/s10347-014-0411-7

PEREZ-HUERTA, A. \& SHELDON, N.D. (2006): Pennsylvanian sea level cycles, nutrient availability, and brachiopod community structure.- Paleogeography, Palaeoclimatology, Palaeoecology, 230/3, 264-279. doi: 10.1016/j.palaeo.2005.07.020

RAZUM, I., MIKO, S., ILIJANIĆ, N., HASAN, O., ŠPARICA MIKO, M., BRUNOVIĆ, D. \& V. PAWLOWSKY-GLAHN, V. (2020): A compositional approach to the reconstruction of geochemical processes involved in the evolution of Holocene marine flooded coastal karst basins (Mljet Island, Croatia).- Applied Geochemistry, 116, 104574. doi: 10.1016/j.apgeochem.2020.104574

ROGAN ŠMUC, N., DOLENEC, T., KRAMAR, S. \& MLADENOVIĆ, A. (2018): Heavy Metal Signature and Environmental Assessment of Nearshore Sediments: Port of Koper (Northern Adriatic Sea).- Geosciences, 8/11, 398. doi: 10.3390/geosciences 8110398

RUBINIĆ, V., LAZAREVIĆ, B., HUSNJAK, S. \& DURN, G. (2015): Climate and relief influence on particle size distribution and chemical properties of Pseudogley soils in Croatia. - Catena, 127, 340-348. doi: 10.1016/j.catena.2014.12.024

SCHWERTMANN, U. (1964): Differenzierung der Eisenoxide des Bodens durch photochemische Extraktion mit saurer Ammoniumoxalat-lösung.- Z. Pflanzenernähr. Bodenkund., 105, 194-202. doi: 10.1002/jpln.3591050303

SHELDON, N.D. (2006): Abrupt chemical weathering increase across the Permian-Triassic boundary.- Paleogeography, Palaeoclimatology, Palaeoecology, 231/3-4, 315-321. doi: 10.1016/j.palaeo.2005.09.001

SHELDON, N.D. \& TABOR, N.J. (2009): Quantitative paleoenvironmental and paleoclimatic reconstruction using paleosols.- Earth-Science Reviews, 95/1-2, 1-52. doi: 10.1016/j.earscirev.2009.03.004

SOIL SCIENCE DIVISION STAFF (2017): Soil survey manual.- In:DITZLER, C., SCHEFFE, K. \& MONGER, H.C. (eds.): USDA Handbook 18 Government Printing Office, Washington, D.C.

SONDI, I., JURAČIĆ, M., PROHIĆ, E. \& PRAVDIĆ, V. (1994): Particulates and the environmental capacity for trace metals: A small river as a model for a land-sea transfer system: the Raša River estuary.- Science of the Total Environment, 155/2, 173-185. doi: 10.1016/0048-9697(94)90290-9

SONDI, I. \& JURAČIĆ, M. (2010): Whiting events and the formation of aragonite in Mediterranean Karstic Marine Lakes: new evidence on its biologically induced inorganic origin.- Sedimentology, 57/1, 85-95. doi: 10.1111/j.1365-3091.2009.01090.X

SONDI, I., MIKAC, N., VDOVIĆ, N., IVANIĆ, M., FURDEK, M. \& ŠKAPIN, S.D. (2017): Geochemistry of recent aragonite-rich sediments in Mediterranean karstic marine lakes: Trace elements as pollution and palaeoredox proxies and indicators of authigenic mineral formation.- Chemosphere, 168, 786-797. doi: 10.1016/j.chemosphere.2016.10.134

SURIĆ, M., JURAČIĆ, M., HORVATINČIĆ, N. \& KRAJCAR BRONIĆ, I. (2005): Late Pleistocene-Holocene sea-level changes and pattern of karstic coasts submersionrecords from submerged speleothems along the Eastern Adriatic Coast (Croatia).Marine Geology, 214/1-3, 163-175. doi: 10.1016/j.margeo.2004.10.030

TOMADIN, L. (2000): Sedimentary fluxes and different dispersion mechanisms of the clay sediments in the Adriatic Basin.- Rendiconti Lincei. Scienze Fisiche e Naturali, 11/3, 161-174. doi: 10.1007/BF02904649

URE, A.M., QUEVAUVILLER, PH., MUNTAU, H. \& GRIEPINK, B. (1993): Speciation of heavy metal in soils and sediments. An account of the improvement and harmonisation of extraction techniques undertaken under the auspices of the BCR of the Commission of the European Communities.- International Journal of Environmental Analytical Chemistry, 51/1-4, 135-151. doi: 10.1080/03067319308027619

VODYANITSKII, Y.N., VASILEV, A.A., VLASOV, M.N. \& KOROVUSHKIN, A.V. (2009): The role of iron compounds in fixing heavy metals and arsenic in alluvial and soddy-podzolic soils in the Perm area Eurasian.- Soil Science, 42, 738-749. doi: $10.1134 /$ S1064229309070047 